\title{
Pengembangan Model Persediaan Continuous Review dengan All-Unit Discount dan Faktor Kadaluwarsa
}

\author{
Cherish Rikardo ${ }^{*}$, Dharma Lesmono², Taufik Limansyah ${ }^{2}$
}

\begin{abstract}
This article discusses a mathematical inventory model that involves expiration date and all-unit discount factor. This model assumes that demand is deterministic and depends to inventory level, deteriorating rate as a function of time and with no lead time. This model is more realistic compared to previous research on deterministic inventory model with constant deterioration rate and no quantity discount. Using this model, we will determine the optimum order quantity (economic order quantity) and the optimum ordering time that minimizes the total annual cost. The algorithm for determination of the optimum solution is also developed and a numerical example as an illustration of the inventory problems is given. Determination of the optimal solution is conducted with the help of MAPLE software. The simulation shows that the deteriorating rate and demand rate are inversely proportional to the optimum ordering time and optimum order quantity.
\end{abstract}

Keywords: Inventory, expiration date, all unit discount.

\section{Pendahuluan}

Persediaan adalah barang-barang yang disimpan untuk digunakan atau dijual pada suatu periode tertentu. Persediaan diperlukan untuk keberlangsungan proses di dalam industri manufaktur maupun industri niaga. Ketersediaan persediaan dalam jumlah besar dapat mengurangi terjadinya kekurangan barang, tetapi diperlukan biaya penyimpanan yang cukup besar. Komponen biaya yang tersimpan di dalam persediaan perlu dipertimbangkan oleh perusahaan, di dalam mengatur keseimbangan antara ketersediaan persediaan dan biaya yang tersimpan di dalam persediaan tersebut. Pengaturan ini menunjukkan pentingnya manajemen persediaan yang menyebabkan persediaan menjadi topik yang banyak dikembangkan dalam berbagai penelitian.

Berbagai model persediaan telah dibuat dengan mempertimbangkan berbagai faktor, seperti diskon, kenaikan harga, laju inflasi dan masa kadaluwarsa. Laju kadaluwarsa menjadi salah satu faktor yang banyak diteliti, karena dengan adanya faktor kadaluwarsa, barang akan mempunyai masa pakai tertentu, dan setelah melewati masa kadaluwarsa barang, biasanya barang tersebut tidak memiliki nilai ekonomis lagi. Hal ini tentunya akan menjadi pertimbangan dari suatu perusahaan terhadap manajemen persediaannya.

\footnotetext{
1 Fakultas Teknologi Industri, Jurusan Teknik Industri, Universitas Katolik Parahyangan, Jl. Ciumbuleuit 94, Bandung 40141. Email: cherish@unpar.ac.id

2 Fakultas Teknologi Informasi dan Sains, Jurusan Matematika, Universitas Katolik Parahyangan, Jl. Ciumbuleuit 94, Bandung 40141. Email: jdharma@unpar.ac.id, taufik.limansyah@unpar.ac.id

* Penulis korespondensi
}

Prasetyo et al. [1] telah mengembangkan suatu model persediaan bahan baku dengan mempertimbangkan faktor diskon dan faktor kadaluwarsa. Limansyah [2] mengembangkan model yang telah dibuat oleh Prasetyo et al. [1] dengan mempertimbangkan faktor all-unit discount dan melakukan perbaikan atas algoritma yang digunakan. Limansyah dan Lesmono [3] telah mengembangkan model persediaan multi item dengan permintaan bersifat deterministik dan mempertimbangkan faktor kadaluarsa dan faktor all unit discount.

Selain itu, banyak penelitian tentang model persediaan yang dibuat dengan mempertimbangkan faktor kadaluwarsa dengan menambah faktor-faktor lain. Dye [4] mengembangkan suatu model persediaan untuk barang yang mengalami kadaluwarsa dengan harga pembelian sebagai fungsi dari kebijakan kredit perusahaan. Kumar et al. [5] membuat suatu model dengan mengasumsikan bahwa permintaan dapat dinyatakan dalam fungsi kuadratik dan biaya penyimpanan yang tidak menentu. Mishra [6] membuat model persediaan dengan mengasumsikan bahwa laju kerusakan atau laju kadaluwarsa barang (deteriorating rate) mengikuti distribusi Weibul dan biaya penyimpanan merupakan fungsi linear terhadap waktu. Mishra et al. [7] membuat model persediaan untuk barang yang mengalami kadaluwarsa dengan mempertimbangkan permintaan dan biaya simpan yang bergantung terhadap waktu. Penelitian lain juga mengembangkan model persediaan barang dengan mempertimbangkan faktor kadaluwarsa dan laju inflasi, misalnya Jaggi and Khanna [8] yang mengembangkan model persediaan berkaitan dengan proses produksi dan penjualan, Dipak et al. [9] yang mengembangkan model dengan menggunakan pendekatan algoritma fuzzy, dan Muniappan et al. [10] yang 
mengembangkan model dengan mempertimbangkan time value of money dan pembayaran yang dapat ditunda. Nagare dan Dutta [11] mengembangkan suatu model persediaan continuous review dengan mempertimbangkan masa kadaluwarsa dan permintaan yang bergantung pada tingkat persediaan.

Zhang dan Wang [12] telah mengembangkan suatu model persediaan multi item dengan masa kadaluwarsa serta mempertimbangkan keterbatasan kapasitas gudang untuk menyimpan barang-barang tersebut. Nafisah et al. [13] mengembangkan model persediaan pada produk yang mendekati masa kadaluwarsa dengan mempertimbangkan diskon penjualan dan retur. Pada Nafisah et al. [13] laju permintaan diasumsikan konstan tetapi berbedabeda yang merupakan fungsi terhadap waktu, yang nantinya tingkat persediaan akan mengikuti trapezoidal type demand rate.

Banyaknya penelitian mengenai model persediaan dengan memperhatikan faktor kadaluwarsa menunjukan bahwa masa kadaluwarsa merupakan salah satu komponen yang penting untuk diperhatikan oleh perusahaan, terutama barang-barang dengan masa kadaluwarsa tertentu, seperti bahan makanan, obat-obatan dan bahan kimia. Suatu perusahaan yang bergerak pada produksi atau penjualan barang perlu memperhatikan masa kadaluwarsa mengingat setelah masa kadaluwarsa barang tidak dapat digunakan atau dikonsumsi, sehingga persediaan yang ada tidak dapat dijual setelah masa kadaluwarsa.

Pada beberapa barang, terutama barang-barang konsumsi seperti makanan, sayur dan buahbuahan, seringkali laju kerusakan atau laju kadaluwarsa tidaklah konstan tetapi bergantung terhadap waktu. Dengan laju kadaluwarsa yang bergantung terhadap waktu, maka semakin lama barang disimpan maka akan semakin banyak barang yang rusak. Beberapa perusahaan akan menggunakan strategi dengan hanya memesan sedikit barang untuk mencegah barang menjadi rusak. Untuk mengatasi hal ini, dari sisi supplier, dilakukan promosi dengan memberikan diskon baik all-unit discount maupun incremental discount untuk meningkatkan pembelian. Perusahaan tentunya ingin memanfaatkan promosi yang diberikan oleh supplier, namun terdapat risiko kadaluwarsa dan biaya penyimpanan yang semakin besar. Model ini dikembangkan untuk menggambarkan kondisi nyata seperti ini termasuk di dalam penentuan solusi optimalnya. Model yang telah dibuat oleh Nagare dan Dutta [11] mengasumsikan bahwa laju kadaluwarsa konstan.Hal ini belum dapat menggambarkan dengan baik kondisi yang ada. Oleh karena ini model ini akan dikembangkan dengan mengubah faktor kadaluwarsa menjadi suatu fungsi yang bergantung terhadap waktu. Selain itu faktor all-unit discount turut diperhitungkan untuk menggambarkan kondisi yang umum terjadi.

\section{Metode Penelitian}

Pada model persediaan klasik, biasanya permintaan diasumsikan konstan atau bergantung kepada waktu. Pada kenyataannya, permintaan ada yang bergantung terhadap faktor lain, seperti harga, merek, dan jumlah persediaan. Untuk beberapa barang tertentu, jika persediaan barang sedikit akan menimbulkan persepsi bahwa barang yang dijual tidak baru ataupun tidak segar. Berdasarkan pertimbangan ini, beberapa penelitian telah dilakukan untuk menguji apakah tingkat persediaan dapat mempengaruhi permintaan atau dengan kata lain, apakah permintaan akan barang bergantung terhadap jumlah persediaan.

Levin et al. [14] menyatakan bahwa banyaknya barang yang ditampilkan pada rak barang dapat menarik minat pembeli untuk membeli barang tersebut. Silver dan Peterson [15] menyatakan bahwa penjualan barang pada industri retail sebanding dengan banyaknya barang yang dipajang. Penelitian ini memberikan contoh bahwa pada bidang retail seperti supermarket, toko fashion seperti toko baju, toko sepatu, dan lainnya mempunyai permintaan yang dipengaruhi oleh jumlah barang yang dipajang. Barang yang dipajang ini dapat dipandang sebagai persediaan yang dimiliki oleh toko tersebut. Dapat disimpulkan bahwa untuk jenis usaha retail, permintaan akan dipengaruhi oleh tingkat persediaan. Berdasarkan penelitian ini pula, model persediaan dengan tingkat permintaan yang bergantung pada tingkat persediaan (inventory dependent demand) banyak dikembangkan dengan mempertimbangkan faktor lainnya seperti faktor kadaluwarsa. Salah satu model persediaan dengan permintaan yang bergantung terhadap tingkat persediaan adalah model persediaan yang dibuat oleh Nagare dan Dutta [11]. Model ini mengasumsikan bahwa permintaan barang dengan masa kadaluwarsa akan bergantung kepada tingkat persediaan dari barang tersebut.

Pada paper ini akan dikembangkan suatu model persediaan dengan mempertimbangkan faktor kadaluwarsa dan all-unit discount yang didasarkan pada model yang dibuat oleh Nagare dan Dutta [11]. Ide awal model ini didasari dengan asumsi bahwa perubahan tingkat persediaan dipengaruhi oleh laju kadaluwarsa dan permintaan. Misal pada saat mulamula $(t=0)$ sebuah perusahaan membeli barang sebesar $I(0)=Q$. 


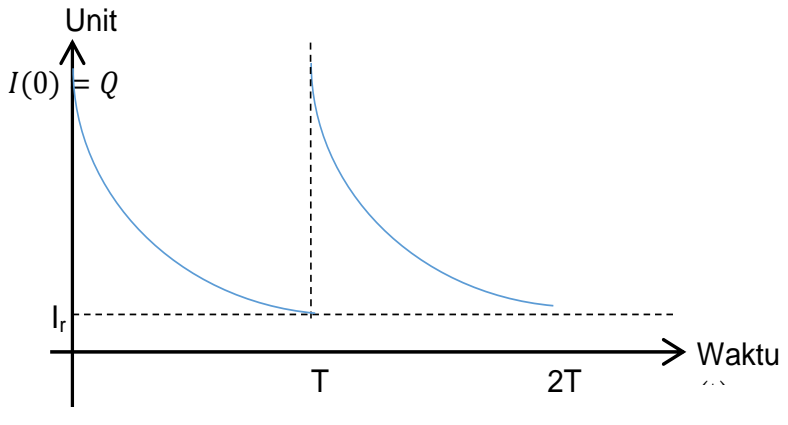

Gambar 1. Grafik tingkat persediaan

Barang yang dibeli merupakan barang yang mempunyai masa kadaluwarsa tertentu, artinya seiring berjalannya waktu barang akan mengalami kerusakan sehingga tidak dapat dijual. Selain adanya barang yang rusak, sebagian barang tentu dijual untuk memenuhi permintaan konsumen. Kedua hal ini menyebabkanpersediaan barang yang mulamula sebesar $I(0)=Q$ akan terus berkurang dengan laju tertentu. Gambar 1 merupakan grafik yang dapat memberikan ilustrasi mengenai perubahan tingkat persediaan terhadap waktu. Adapun asumsi yang digunakan adalah bahwa barang yang rusak tidak dapat dijual, diperbaiki ataupun dikembalikan kepada supplier, tingkat permintaan pada model ini merupakan suatu fungsi yang bergantung terhadap tingkat persediaan dan satu periode perencanaan adalah satu tahun.

\section{Pengembangan Model}

Notasi yang digunakan dalam pengembangan model persediaan ini adalah:

TAC

$T$

$T^{*}$

$I(0)=Q$

$D(t)=\alpha+\beta I(t)$

$I(t)$

$\theta(t)=\theta t$

$I_{r}$ $P_{i}=\left\{\begin{array}{c}P_{1} ; 0<I(0)<U_{1} \\ P_{2} ; U_{1} \leq I(0)<U_{2} \\ \vdots \\ P_{j} ; U_{j-1} \leq I(0)<U_{j}\end{array}:\right.$

: total biaya persediaan tahunan

: lamanya siklus persediaan

: lamanya siklus persediaan yang optimal

: jumlah barang yang dibeli di awal siklus persediaaan

: tingkat permintaan pada saat $t$

: tingkat persediaan pada saat $t$

: laju kadaluwarsa (kerusakan) barang pada saat $t$

: reserve inventory di akhir siklus

harga beli barang per unit,

dengan $P_{1}>P_{2}>\cdots>P_{j}$ $\operatorname{dan} U_{1}<U_{2}<\cdots<U_{j}$
$M(T)$

$h(t)=a+b t^{2}$

$H(T)$

$C_{1}$

$R(T)$

Berdasarkan notasi dan asumsi yang digunakan, model persediaan ini dapat dinyatakan sebagai:

$$
\begin{aligned}
\frac{d I(t)}{d t} & =-\theta t I(t)-(\alpha+\beta I(t)) \\
& =-(\theta t+\beta) I(t)-\alpha
\end{aligned}
$$

Persamaan (1) merupakan persamaan diferensial linear orde satu, sehingga solusi bagi persamaan (1) adalah:

$I(t)=-\frac{\alpha \int e^{\frac{\theta t^{2}}{2}+\beta t} d t}{e^{\frac{\theta t^{2}}{2}+\beta t}}$

Pada persamaan (2) terdapat bentuk $\int e^{\frac{\theta t^{2}}{2}+\beta t} d t$, yang tidak dapat diintegralkan. Agar bentuk ini dapat dihitung integralnya, digunakan hampiran dengan menggunakan deret Maclaurin orde kedua, yaitu:

$e^{\frac{\theta t^{2}}{2}+\beta t} \approx 1+\beta t+\left(\frac{1}{2} \beta^{2}+\frac{1}{2} \theta\right) t^{2}$

$e^{-\left(\frac{\theta t^{2}}{2}+\beta t\right)} \approx 1-\beta t+\left(\frac{1}{2} \beta^{2}+\frac{1}{2} \theta\right) t^{2}$

sehingga solusi bagi persamaan (2) adalah

$$
\begin{array}{r}
I(t)=-\alpha\left(1-\beta t+\left(\frac{1}{2} \beta^{2}+\frac{1}{2} \theta\right) t^{2}\right) \\
\int 1+\beta t+\left(\frac{1}{2} \beta^{2}+\frac{1}{2} \theta\right) t^{2} d t \\
=-\alpha\left(1-\beta t+\left(\frac{\beta^{2}+\theta}{2}\right) t^{2}\right) \\
\left(t+\frac{\beta t^{2}}{2}+\left(\frac{\beta^{2}+\theta}{6}\right) t^{3}+\mathrm{K}\right)
\end{array}
$$

dengan $K$ adalah konstanta yang diperoleh dari hasil integral tak tentu. Nilai $K$ akan dicari dengan menggunakan syarat batas $I(T)=I_{r}$ sehingga persamaan (5) dapat ditulis sebagai:

$$
\begin{aligned}
& I(t)=-\alpha\left(1-\beta t+\left(\frac{\beta^{2}+\theta}{2}\right) t^{2}\right)\left(t+\frac{\beta t^{2}}{2}+\left(\frac{\beta^{2}+\theta}{6}\right) t^{3}+\right. \\
& \left.\frac{I_{r}}{-\alpha\left(1-\beta T+\left(\frac{\beta^{2}+\theta}{2}\right) T^{2}\right)}-\left(T+\frac{\beta T^{2}}{2}+\left(\frac{\beta^{2}+\theta}{6}\right) T^{3}\right)\right)
\end{aligned}
$$


Biaya-biaya yang terlibat di dalam model ini meliputi biaya pembelian, biaya pemesanan, biaya penyimpanan dan biaya kerusakan barang:

Biaya pembelian adalah banyaknya barang yang dibeli dikalikan dengan harga barang per unit, yaitu:

$$
\begin{aligned}
& M(T)=P_{i} \times\left(I(0)-I_{r}\right) \\
& =P_{i}\left(\frac{I_{r}}{\left(1-\beta T+\left(\frac{\beta^{2}+\theta}{2}\right) T^{2}\right)}+\alpha\left(T+\frac{\beta T^{2}}{2}+\left(\frac{\beta^{2}+\theta}{6}\right) T^{3}\right)-I_{r}\right)
\end{aligned}
$$

Biaya pemesanan adalah konstan sebesar $C_{1}$ per sekali pemesanan. Biaya penyimpanan adalah banyaknya barang yang disimpan dikalikan dengan biaya simpan barang per unit per satuan waktu.

$H(T)=\int_{0}^{T} h(t) I(t) d t=\int_{0}^{T}\left(a t^{2}+b\right) I(t) d t$

Biaya kerusakan adalah biaya yang muncul akibat adanya barang mengalami kerusakan dan tidak dapat dijual. Besar biaya kerusakan adalah banyaknya barang yang mengalami kerusakan dikalikan dengan harga pemebelian, yaitu:

$R(T)=P_{i} \int_{0}^{T} \theta t I(t) d t$

sehingga diperoleh biaya total persediaan per tahun adalah:

$\operatorname{TAC}(T)=\frac{M(T)}{T}+\frac{C_{1}}{T}+\frac{H(T)}{T}+\frac{R(T)}{T}$

$=P_{i}\left(\frac{I_{r}}{\left(T-\beta T^{2}+\left(\frac{\beta^{2}+\theta}{2}\right) T^{3}\right)}+\alpha\left(1+\frac{\beta T}{2}+\left(\frac{\beta^{2}+\theta}{6}\right) T^{2}\right)-\frac{I_{r}}{T}\right)+$

$\frac{C_{1}}{T}+\frac{1}{T} \int_{0}^{T}\left(a t^{2}+b\right) I(t) d t+\frac{P_{i}}{T} \int_{0}^{T} \theta t I(t) d t$

Nilai $T$ yang meminimumkan biaya total persediaan adalah nilai $T$ yang memenuhi syarat perlu sebagai berikut:

$\frac{d T A C}{d T}=0$

$\frac{d T A C}{d T}=P_{i}\left(\frac{-I_{r}\left(1-2 \beta T+3\left(\frac{\beta^{2}+\theta}{2}\right) T^{2}\right)}{\left(T-\beta T^{2}+\left(\frac{\beta^{2}+\theta}{2}\right) T^{3}\right)^{2}}+\alpha\left(1+\frac{\beta}{2}+\right.\right.$

$\left.\left.\left(\frac{\beta^{2}+\theta}{3}\right) T\right)+\frac{I_{r}}{T^{2}}\right)-\frac{C_{1}}{T^{2}}-\frac{1}{T^{2}} \int_{0}^{T}\left(a t^{2}+b\right) I(t) d t+$

$\frac{1}{T}\left(a T^{2}+b\right) I_{r}-\frac{1}{T^{2}} \int_{0}^{T} \theta t I(t) d t+\theta I_{r}=0$

Misal $T^{*}$ adalah nilai $T$ yang dapat memenuhi persamaan (10), selanjutnya akan dihitung turunan kedua dari TAC terhadap $T$ untuk menjamin bahwa nilai $T^{*}$ adalah nilai $T$ yang meminimumkan $T A C$

Turunan kedua TAC terhadap $T$ adalah:

$$
\begin{aligned}
& \frac{d^{2} T A C}{d T^{2}}=P S_{i}+\frac{2 C_{1}}{T^{3}}+\frac{2}{T^{3}} \int_{0}^{T}\left(a t^{2}+b\right) I(t) d t- \\
& \frac{1}{T^{2}}\left(a T^{2}+b\right) I_{r}+\left(a-\frac{b}{T^{2}}\right) I_{r}+\frac{2}{T^{3}} \int_{0}^{T} \theta t I(t) d t
\end{aligned}
$$

dengan

$S_{1}=\frac{I_{r}\left(2 \beta-3\left(\beta^{2}+\theta\right) T\right)\left(T-\beta T^{2}+\left(\frac{\beta^{2}+\theta}{2}\right) T^{3}\right)+I_{r}\left(1-2 \beta T+3\left(\frac{\beta^{2}+\theta}{2}\right) T^{2}\right)^{2}}{\left(T-\beta T^{2}+\left(\frac{\beta^{2}+\theta}{2}\right) T^{3}\right)^{3}}-$

$\alpha\left(\frac{\beta^{2}+\theta}{3}\right)-\frac{2 I_{r}}{T^{3}}$

Perhatikan bahwa:

$P_{i} S_{1}+\frac{2 C_{1}}{T^{3}}+\frac{2}{T^{3}} \int_{0}^{T}\left(a t^{2}+b\right) I(t) d t+\left(a-\frac{b}{T^{2}}\right) I_{r}+$

$\frac{2}{T^{3}} \int_{0}^{T} \theta t I(t) d t>\frac{1}{T^{2}}\left(a T^{2}+b\right) I_{r}$

sehingga $\frac{d^{2} T A C}{d T^{2}}>0$. Maka berdasarkan uji turunan kedua, diperoleh bahwa nilai $T^{*}$ yang memenuhi persamaan (11) akan meminimumkan total biaya persediaan $T A C$.

Nilai $T^{*}$ yang memenuhi persamaan (11) tidak dapat dinyatakan dalam bentuk eksplisit, sehingga untuk menghitung nilai $T^{*}$ akan digunakan software MAPLE. Selain itu, nilai $T^{*}$ yang ingin dicari memuat $P_{i}$, dimana $P_{i}$ akan bergantung terhadap banyaknya barang yang dibeli di awal siklus yaitu $I(0)=Q$. Hal ini menyebabkan nilai-nilai yang ingin dicari saling bergantung, untuk mengatasi hal ini digunakan algoritma perhitungan dengan beberapa langkah sebagai berikut:

Hitung nilai $T^{*}$ untuk setiap nilai $P_{i}$

Berdasarkan nilai $T^{*}$ yang diperoleh pada langkah pertama, hitung banyaknya barang yang dibeli, yaitu $Q=I(0)$

Periksa apakah nilai $Q$ yang diperoleh sudah valid. Jika valid, maka dapat langkah 4 dapat dilakukan. Pengertian valid di sini adalah nilai $Q$ yang diperoleh berada pada harga beli barang yang tepat.

Tetapi jika $Q$ tidak valid, maka:

Untuk nilai $Q<U_{j-1}$ pilih $Q=U_{j-1}$

Untuk $Q>U_{j}$ pilih $Q=U_{j}$.

Hitung kembali nilai $T$ untuk $Q$ yang tidak valid. Hitung total biaya persediaan untuk setiap nilai $T^{*}$ dan $Q$ yang telah diperoleh.

Bandingkan nilai $T A C$ yang diperoleh, dan pilihlah nilai $T A C$ yang minimum.

Algoritma ini diringkas dalam diagram alir yang terdapat pada Gambar 2.

Tabel 1. Harga pembelian barang

\begin{tabular}{cc}
\hline Harga & Jumlah Pembelian (unit) \\
\hline Rp 12.000 & $\leq 100$ \\
$\operatorname{Rp} 11.000$ & $101-200$ \\
$\operatorname{Rp} 10.000$ & $\geq 201$ \\
\hline
\end{tabular}




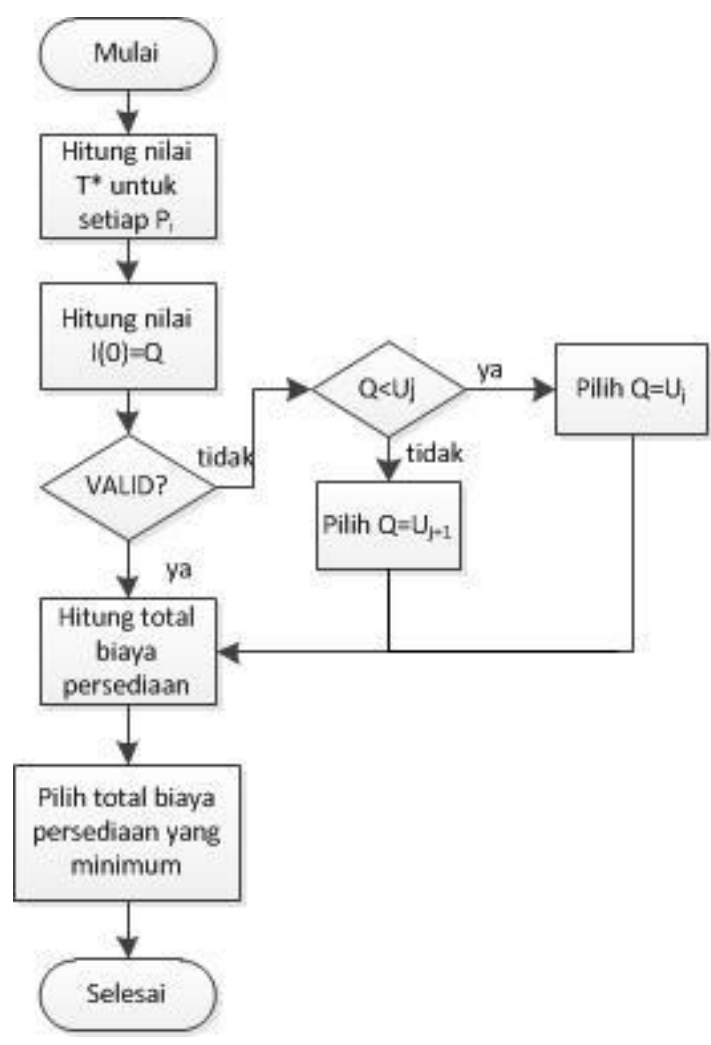

Gambar 2 Diagram alir pencarian solusi optimum

\section{Hasil dan Pembahasan}

Pada bagian ini akan diberikan contoh numerik untuk model yang telah dikembangkan pada bagian sebelumnya. Suatu perusahaan yang bergerak di bidang penjualan bahan makanan dapat membeli barang dengan promosi all-unit discount dari supplier, dengan harga diberikan pada Tabel 1. Biaya pemesanan adalah sebesar Rp 100.000. Biaya simpan terdiri atas biaya penyewaan tempat dan biaya perawatan barang. Besarnya biaya penyewaan tempat adalah sebesar Rp 500 per unit, sedangkan biaya perawatan barang akan bergantung kepada durasi barang tersebut disimpan (kuadrat waktu), yaitu sebesar $\mathrm{Rp} 10$ per unit barang. Biaya penyimpanan per unit terdiri atas biaya penyewaan tempat, yaitu $\mathrm{Rp} 500,00$ per unit dan biaya pemeliharaan yang bergangung pada lamanya barang disimpan, yaitu sebesar Rp $10 \mathrm{t}^{2}$ per unit. Sehingga biaya penyimpanan dapat dituliskan sebagai fungsi yang bergantung kepada waktu, yaitu $h(t)=\operatorname{Rp}\left(500+10 t^{2}\right)$ per unit.

Jika laju kadaluwarsa barang dapat dinyatakan dalam fungsi $\theta(t)=0,2 t$ dan tingkat permintaan saat $t$ dapat dinyatakan sebagai $D(t)=800+$ $0,3 I(t)$ dengan $I(t)$ adalah jumlah persediaan saat $t$. Pada akhir siklus, perusahaan tidak menginginkan adanya barang sisa di gudang sehingga nilai reserve inventory $I_{r}=0$. Berdasarkan persamaan (6), diperoleh persediaan saat $t$ sebesar:

$$
\begin{aligned}
& I(t)=-800\left(1-0,3 t+0,145 t^{2}\right)\left(t+\frac{0,3 t^{2}}{2}+\right. \\
& \left.0,04833 t^{3}-\left(T+\frac{0,3 T^{2}}{2}+(0,04833) T^{3}\right)\right)
\end{aligned}
$$

Biaya-biaya yang terjadi dalam satu siklus kecil persediaan barang meliputi biaya-biaya sebagai berikut:

Biaya pemesanan sebesar Rp 100.000 per sekali pemesanan

Biaya pembelian sebesar

$$
\begin{aligned}
& M(T)=P_{i}\left(800 \times\left(T+\frac{0.3 T^{2}}{2}+(0,04833) T^{3}\right)\right) \\
& \text { dengan } P_{i}=\left\{\begin{array}{c}
12000 ; Q \leq 100 \\
11000 ; 101 \leq Q \leq 200 \\
10000 ; Q \geq 201
\end{array}\right.
\end{aligned}
$$

Biaya penyimpanan sebesar

$H(T)=\int_{0}^{T}\left(50 t^{2}+500\right) I(t) d t$

Biaya kerusakan sebesar

$R(T)=\int_{0}^{T} 0,2 t I(t) d t$

Biaya total dalam satu siklus per satuan waktu dan turunan pertama dari biaya total masing-masing diberikan oleh;

$T A C=P_{i}\left(800 \times\left(1+\frac{0,3 T}{2}+0,04833 T^{2}\right)\right)+\frac{100000}{T}+$
$\frac{1}{T} \int_{0}^{T}\left(50 t^{2}+500\right) I(t) d t+\frac{1}{T} \int_{0}^{T} 0,2 t I(t) d t$

$\frac{d T A C}{d T}=800 P_{i}(0,15+0,9666 T)-\frac{100000}{T^{2}}$

$\frac{1}{T^{2}} \int_{0}^{T}\left(50 t^{2}+500\right) I(t) d t+\frac{1}{T}\left(50 T^{2}+500\right)-$

$\frac{1}{T^{2}} \int_{0}^{T} 0,2 t I(t) d t+0,2 I_{r}=0$

Nilai $T$ yang minimum adalah nilai $T$ yang memenuhi persamaan (20). Gambar 3 merupakan grafik dari total biaya persediaan, dapat dilihat pada gambar, bahwa total biaya persediaan akan minimum di antara nilai $T=0,2$.

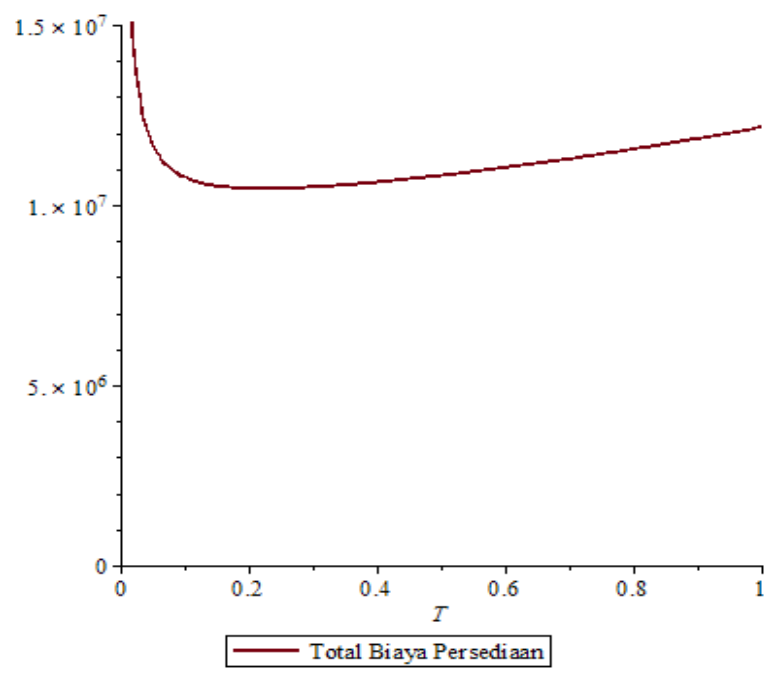

Gambar 3. Grafik total cost 
Menggunakan program MAPLE dan algoritma yang telah dijelaskan pada bagian sebelumnya, diperoleh nilai $T$ dan $Q$ (lihat Tabel 2)

Berdasarkan hasil perhitungan yang dimuat pada Tabel 2 dapat dilihat bahwa untuk harga Rp 12.000 diperoleh jumlah pesanan $(Q)$ adalah 185 unit, hal ini tidak valid karena supplier membatasi pembelian maksimal 100 unit, sehingga untuk harga Rp 12.000 dipilih $Q=100$ dan akan dihitung kembali nilai $T$ yang memenuhi, demikian pula untuk jumlah barang pada harga Rp 10.000. Untuk harga Rp 11.000 diperoleh nilai $Q$ yang sudah valid, maka nilai $T A C$ dapat langsung dihitung.

Berdasarkan hasil perhitungan yang diperoleh pada Tabel 3, dapat dilihat bahwa nilai TAC yang minimum diberikan oleh pembelian sebanyak 201 unit. Untuk pemesanan 201 unit, waktu pemesanan kembali adalah setelah 0,241 tahun atau setelah 3 bulan dari pemesanan pertama. Berdasarkan hasil perhitungan ini, maka sebaiknya perusahaan, dalam satu tahun perencanaan, melakukan 4 kali pemesanan barang sebanyak 201 unit untuk setiap kali pemesanan. Biaya total persediaan dalam satu tahun adalah sebesar Rp 8.752.384,76.

\section{Analisis Sensitivitas}

\section{Pengaruh Laju Kadaluwarsa terhadap Model}

Pada bagian ini ingin dianalisis pengaruh yang diberikan oleh laju kadaluwarsa. Untuk mengetahui pengaruh laju kadaluwarsa terhadap model, maka akan dihitung kembali jumlah pemesanan dan waktu pemesanan optimum yang meminimumkan total biaya persediaan (TAC) untuk beberapa nilai $\theta$. Pada Tabel 3, dapat dilihat bahwa semakin besar laju kadaluwarsa akan menyebabkan periode pemesanan semakin pendek dan jumlah barang yang dipesan semakin sedikit. Gambar 4 dapat memberikan gambaran mengenai hubungan antara laju kadaluwarsa $(\theta)$, jumlah pembelian $(Q)$ dan waktu antar pemesanan $(T)$.

Tabel 2. Hasil perhitungan $T$ dan $Q$

\begin{tabular}{cccc}
\hline Harga & $\mathrm{T}$ & $\mathrm{Q}$ & $\begin{array}{c}\text { Valid / Tidak } \\
\text { Valid }\end{array}$ \\
\hline Rp 12.000 & 0,223 & 185,0193 & Tidak valid \\
Rp 11.000 & 0,231 & 191,943 & Valid \\
Rp 10.000 & 0,240 & 199,742 & Tidak Valid \\
\hline
\end{tabular}

Tabel 3. Hasil perhitungan $T A C$

\begin{tabular}{cccc}
\hline Harga & $T$ & $Q$ & TAC \\
\hline Rp 12.000 & 0,123 & 100 & Rp 10.700.393,31 \\
Rp 11.000 & 0,231 & 192 & Rp $9.654 .303,88$ \\
Rp 10.000 & 0,242 & 201 & Rp $8.752 .384,76$ \\
\hline
\end{tabular}

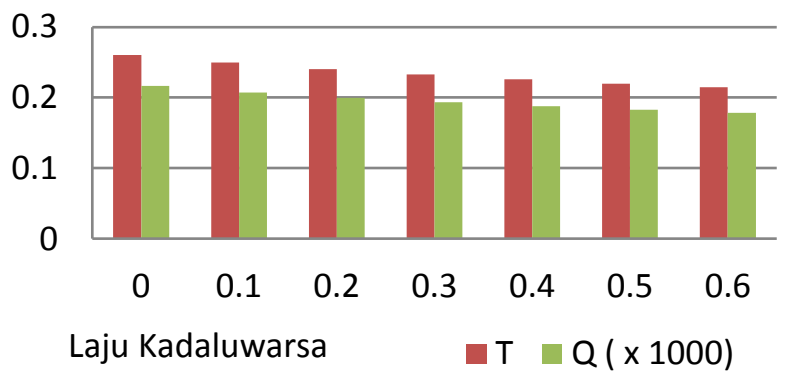

Gambar 4. Grafik pengaruh laju kadaluwarsa terhadap waktu dan jumlah pembelian

Berdasarkan Gambar 4 dapat dilihat bahwa laju kadaluwarsa yang semakin besar menghasilkan waktu antar pemesanan yang lebih cepat dan jumlah barang yang dipesanpun akan semakin sedikit. Hal ini disebabkan karena jika laju kadaluwarsa semakin besar, maka jumlah barang yang rusak atau kadaluwarsa akan semakin banyak. Mengingat bahwa barang rusak ataupun barang kadaluwarsa tidak dapat dijual, maka sebaiknya perusahaan mengurangi jumlah pembelian untuk mengurangi barang yang mengalami kadaluwarsa. Jumlah barang yang lebih sedikit, tentunya menyebabkan barang persediaan akan lebih cepat habis sehingga waktu antar pemesanan akan menjadi lebih singkat.

\section{Pengaruh Laju Permintaan terhadap Model}

Selain dipengaruhi oleh laju kadaluwarsa, model ini juga dipengaruhi oleh permintaan. Untuk melihat hubungan model yang telah dibuat terhadap permintaan, pada bagian ini ingin diselidiki mengenai pengaruh yang diberikan oleh laju permintaan $(\beta)$ terhadap model. Untuk melihat pengaruh laju permintaan akan dihitung nilai $T$ yaitu waktu antar pemesanan dan $Q$ yaitu jumlah pemesanan untuk beberapa nilai $\beta$.

Pada Tabel 4 dapat dilihat bahwa nilai permintaan yang semakin tinggi menyebabkan semakin cepat waktu antar pemesanan dan berkurangnya jumlah barang yang dipesan. Hal ini disebabkan karena dengan permintaan yang besar, barang akan semakin cepat habis sehingga waktu antar pemesanan semakin singkat. Sementara itu, karena waktu pemesanan semakin singkat, maka frekuensi pemesanan dalam satu tahun akan membesar yang menyebabkan total biaya pemesanan akan semakin besar. Untuk mengatasi hal ini, maka kuantitas barang yang dipesan akan lebih sedikit dengan tujuan untuk mengurangi biaya penyimpanan dan mengurangi risiko barang yang disimpan mengalami kadaluwarsa dan tidak dapat dijual. Gambar 5 memberikan gambaran mengenai hubungan antara laju permintaan $(\beta)$, jumlah pembelian $(Q)$ dan waktu antar pemesanan $(T)$. 
Tabel 4 Pengaruh tingkat permintaan $(D)$ terhadap $T$ dan $Q$ dengan biaya pemesanan 100000

\begin{tabular}{|c|c|c|c|c|c|c|c|c|c|}
\hline $\begin{array}{c}\text { Laju } \\
\text { Permintaan }\end{array}$ & Harga & $\begin{array}{c}\mathrm{T} \\
\text { Hitung }\end{array}$ & $\begin{array}{c}\mathrm{Q} \\
\text { Hitung }\end{array}$ & $\begin{array}{c}\text { Q } \\
\text { Valid }\end{array}$ & $\begin{array}{c}\mathrm{T} \\
\text { Valid }\end{array}$ & $\begin{array}{c}\text { Biaya } \\
\text { pembelian }\end{array}$ & $\begin{array}{c}\text { Biaya } \\
\text { penyimpanan }\end{array}$ & $\begin{array}{c}\text { Biaya } \\
\text { kerusakan }\end{array}$ & Total biaya \\
\hline \multirow{3}{*}{0} & 12000 & 0,379 & 304,441 & 100 & 0,125 & 1200000 & 3124,979 & 624,847 & $10.505 .483,88$ \\
\hline & 11000 & 0,387 & 311,342 & 200 & 0,249 & 2200000 & 12502,599 & 4580,477 & $9.269 .201,54$ \\
\hline & 10000 & 0,397 & 322,282 & 323 & 0,396 & 3230000 & 32471,948 & 17400,737 & $8.477 .964,30$ \\
\hline & 12000 & 0,303 & 246,688 & 100 & 0,124 & 1200000 & 3099,375 & 615,272 & $10.569 .227,56$ \\
\hline \multirow{3}{*}{0,1} & 11000 & 0,312 & 254,174 & 200 & 0,246 & 2200000 & 12298,477 & 4441,443 & $9.382 .822,68$ \\
\hline & 10000 & 0,322 & 262,498 & 263 & 0,322 & 2630000 & 21082,328 & 9039,419 & $8.549 .587,37$ \\
\hline & 12000 & 0,255 & 209,989 & 100 & 0,123 & 1200000 & 3074,0618 & 605,886 & $10.632 .740,28$ \\
\hline \multirow[t]{3}{*}{0,2} & 11000 & 0,264 & 217,290 & 200 & 0,243 & 2200000 & 12101,703 & 4309,294 & $9.495 .532,83$ \\
\hline & 10000 & 0,274 & 225,468 & 226 & 0,273 & 2260000 & 15318,996 & 5569,761 & $8.683 .781,39$ \\
\hline & 12000 & 0,223 & 185,019 & 100 & 0,123 & 1200000 & 3049,210 & 596,737 & $10.688 .521,04$ \\
\hline \multirow[t]{3}{*}{0,3} & 11000 & 0,231 & 191,943 & 192 & 0,231 & 2112000 & 10992,066 & 3711,327 & $9.610 .624,40$ \\
\hline & 10000 & 0,240 & 199,742 & 201 & 0,242 & 2010000 & 12028,525 & 3858,879 & $8.776 .079,69$ \\
\hline & 12000 & 0,200 & 166,917 & 100 & 0,122 & 1200000 & 3024,807 & 587,816 & $10.735 .811,25$ \\
\hline \multirow[t]{3}{*}{0,4} & 11000 & 0,208 & 173,451 & 174 & 0,208 & 1914000 & 8893,424 & 2692,021 & $9.741 .702,78$ \\
\hline & 10000 & 0,216 & 180,838 & 201 & 0,239 & 2010000 & 11842,683 & 3747,971 & $8.877 .778,32$ \\
\hline & 12000 & 0,183 & 153,129 & 100 & 0,121 & 1200000 & 3000,843 & 579,116 & $10.787 .971,29$ \\
\hline \multirow[t]{3}{*}{0,5} & 11000 & 0,189 & 159,305 & 160 & 0,189 & 1760000 & 7442,427 & 2054,938 & $9.847 .806,41$ \\
\hline & 10000 & 0,198 & 166,307 & 201 & 0,236 & 2010000 & 11663,236 & 3642,309 & $8.978 .651,47$ \\
\hline & 12000 & 0,169 & 142,219 & 100 & 0,120 & 1200000 & 2977,303 & 570,629 & $10.842 .991,99$ \\
\hline \multirow[t]{2}{*}{0,6} & 11000 & 0,175 & 148,080 & 149 & 0,175 & 1639000 & 6385,312 & 1628,867 & $9.952 .561,01$ \\
\hline & 10000 & 0,183 & 171,565 & 201 & 0,234 & 2010000 & 11489,862 & 3541,566 & $9.078 .707,83$ \\
\hline
\end{tabular}

Tabel 5. Pengaruh tingkat permintaan $(D)$ terhadap $T$ dan $Q$ dengan biaya pemesanan tak konstan

\begin{tabular}{|c|c|c|c|c|c|c|c|c|c|}
\hline $\begin{array}{c}\text { Biaya } \\
\text { pemesanan }\end{array}$ & Harga & $\begin{array}{c}\mathrm{T} \\
\text { Hitung }\end{array}$ & $\begin{array}{c}\mathrm{Q} \\
\text { Hitung }\end{array}$ & $\begin{array}{c}\text { Q } \\
\text { Valid } \\
\end{array}$ & $\begin{array}{c}\mathrm{T} \\
\text { Valid } \\
\end{array}$ & $\begin{array}{c}\text { Biaya } \\
\text { pembelian }\end{array}$ & $\begin{array}{c}\text { Biaya } \\
\text { penyimpanan }\end{array}$ & $\begin{array}{c}\text { Biaya } \\
\text { kerusakan }\end{array}$ & Total biaya \\
\hline \multirow{3}{*}{100000} & 12000 & 0,223 & 185,019 & 100 & 0,123 & 1200000 & 3049,210 & 596,737 & $10.623 .762,92$ \\
\hline & 11000 & 0,231 & 191,943 & 192 & 0,231 & 2112000 & 10992,066 & 3711,327 & $9.610 .624,40$ \\
\hline & 10000 & 0,240 & 199,742 & 201 & 0,242 & 2010000 & 12028,525 & 3858,879 & $8.776 .079,69$ \\
\hline \multirow{3}{*}{200000} & 12000 & 0,305 & 256,547 & 100 & 0,123 & 1200000 & 3049,210 & 596,737 & $11.439 .063,13$ \\
\hline & 11000 & 0,316 & 266,089 & 200 & 0,231 & 2200000 & 10992,065 & 3711,327 & $10.423 .401,66$ \\
\hline & 10000 & 0,328 & 276,839 & 277 & 0,328 & 2770000 & 22426,467 & 9753,188 & $9.118 .105,47$ \\
\hline \multirow{3}{*}{300000} & 12000 & 0,365 & 310,082 & 100 & 0,123 & 1200000 & 3049,210 & 596,737 & $12.254 .363,34$ \\
\hline & 11000 & 0,378 & 321,579 & 200 & 0,231 & 2200000 & 10992,066 & 3711,327 & $10.855 .729,98$ \\
\hline & 10000 & 0,392 & 334,536 & 335 & 0,392 & 3350000 & 32331,598 & 16790,686 & $9.389 .312,93$ \\
\hline \multirow{3}{*}{400000} & 12000 & 0,414 & 354,463 & 100 & 0,123 & 1200000 & 3049,2100 & 596,737 & $13.069 .663,55$ \\
\hline & 11000 & 0,428 & 367,581 & 200 & 0,231 & 2200000 & 10992,066 & 3711,327 & $11.288 .058,31$ \\
\hline & 10000 & 0,444 & 382,369 & 383 & 0,444 & 3830000 & 41801,809 & 24573,038 & $9.618 .189,81$ \\
\hline \multirow{3}{*}{500000} & 12000 & 0,456 & 393,071 & 100 & 0,123 & 1200000 & 3049,210 & 596,737 & $13.884 .963,75$ \\
\hline & 11000 & 0,471 & 407,601 & 200 & 0,231 & 2200000 & 10992,066 & 3711,327 & $11.720 .386,64$ \\
\hline & 10000 & 0,489 & 423,984 & 424 & 0,489 & 4240000 & 50942,209 & 32929,524 & $9.806 .590,39$ \\
\hline
\end{tabular}

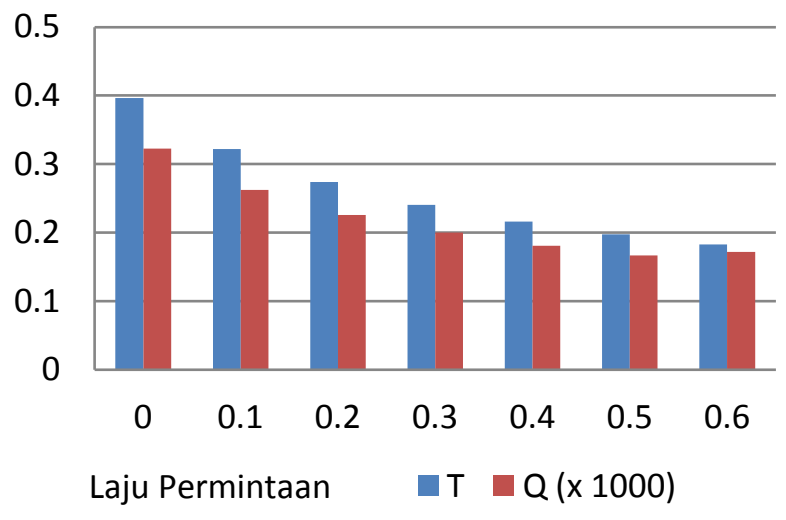

Gambar 5. Grafik pengaruh laju permintaan terhadap waktu dan jumlah pembelian

Pada Gambar 5, dapat dilihat bahwa semakin besar laju permintaan, akan menyebabkan waktu antar pemesanan menjadi semakin singkat dan jumlah barang yang dipesanpun semakin sedikit. Hal ini disebabkan karena waktu antar pemesanan yang singkat menyebabkan perusahaan akan lebih sering membeli barang. Bila frekuensi pemesanan yang semakin besar, maka dalam satu kali pemesanan, jumlah barang yang dipesan akan semakin sedikit.

\section{Pengaruh Biaya Pemesanan Terhadap Model}

Pada bagian ini akan diselidiki pengaruh biaya pemesanan terhadap model. Untuk setiap tingkatan harga akan dihitung nilai $T^{*}$ dan $Q$. Tabel 5 memuat perhitungan biaya berdasarkan biaya pemesanan yang berbeda-beda. Pada Tabel 5 dapat dilihat bahwa biaya pemesanan yang membesar akan menyebabkan membesarnya waktu pemesanan dan jumlah barang yang dipesan, yang pada akhirnya akan menyebabkan kenaikan total biaya persediaan. Kenaikan pada biaya pemesanan akan menyebabkan perusahaan akan memesan lebih jarang namun barang yang dipesan akan semakin banyak, dengan memesan lebih jarang dan lebih banyak akan menyebabkan naiknya biaya penyimpanan. 


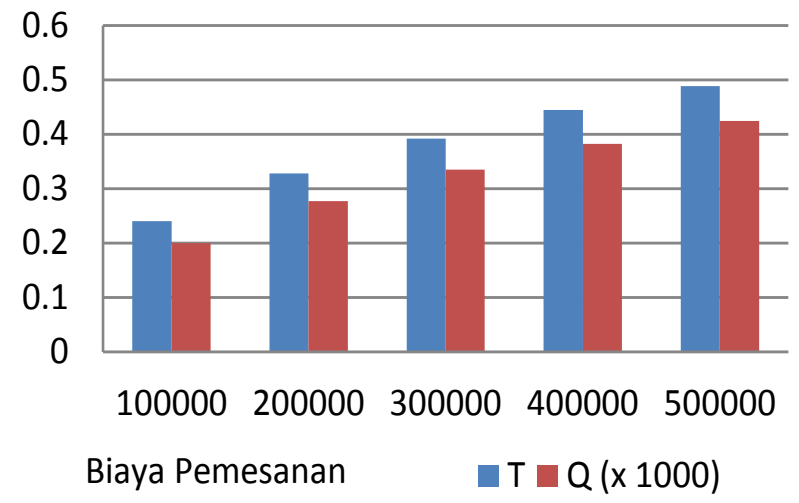

Gambar 6. Grafik pengaruh biaya pemesanan terhadap waktu dan jumlah pembelian

Adanya faktor kadaluwarsa akan menimbulkan risiko adanya barang rusak yang disimpan, selain itu kenaikan biaya simpan tidak sebesar naiknya biaya pemesanan. Untuk menanggulangi naiknya biaya pemesanan akan dipilih waktu pemesanan yang lebih lama dan jumlah pembelian yang lebih besar.

Gambar 6 memberikan gambaran mengenai kenaikan waktu pemesanan dan jumlah pemesanan yang optimal berdasarkan kenaikan biaya pemesanan.

Berdasarkan analisis sensitivitas yang terlampir, dapat dilihat bahwa laju kadaluwarsa, laju pemesanan biaya pemesanan akan mempengaruhi model dengan cukup signifikan. Laju kadaluwasa dan laju permintaan yang membesar akan menyebabkan waktu pemesanan dan jumlah yang dipesan terus berkurang. Biaya pemesanan yang membesar akan menyebabkan waktu pemesanan dan jumlah pemesanan yang juga semakin membesar.

\section{Simpulan}

Pada model yang telah dikembangkan, terdapat beberapa parameter yang mempengaruhi waktu antar pemesanan yang optimal $\left(T^{*}\right)$ dan jumlah pemesanan yang optimal $(Q)$, diantaranya adalah laju kadaluwarsa, tingkat permintaan dan biaya pemesanan. Semakin besar laju kadaluwarsa, maka nilai $T^{*}$ dan $Q$ akan mengecil. Artinya saat laju kadaluwarsa membesar, banyaknya barang akan semakin cepat rusak. Barang yang rusak tidak dapat dijual, sehingga perusahaan sebaiknya memesan barang dalam jumlah yang lebih sedikit namun lebih sering.

Selain itu, besarnya tingkat permintaan $(\beta)$ juga akan mempengaruhi nilai $T^{*}$ dan $Q$. Semakin besar tingkat permintaan, maka nilai $T^{*}$ dan $Q$ akan mengecil. Besarnya tingkat permintaan akan menyebabkan persediaan lebih cepat habis, sehingga perusahaan akan lebih sering memesan barang.
Frekuensi pemesanan yang lebih sering menyebabkan perusahaan akan memesan dengan jumlah yang lebih sedikit. Untuk biaya pemesanan, semakin tinggi biaya pemesanan akan menyebabkan semakin lama waktu pemesanan. Artinya perusahaan akan lebih jarang memesan barang, hal ini dilakukan untuk menekan biaya pemesanan yang semakin membesar. Barang yang dipesan akan semakin banyak untuk memenuhi permintaan pada selang waktu yang lebih lama.

\section{Daftar Pustaka}

1. Prasetyo, H., Nugroho, M.T., dan Pujiarti, A., Pengembangan Model Persediaan Bahan Baku dengan Mempertimbangkan Waktu Kadaluwarsa dan Faktor Unit Diskon, Jurnal Ilmiah Teknik Industri, 4(3), 2006, pp. 115-122.

2. Limansyah, T., Pengembangan Model Persediaan Barang dengan Mempertimbangkan Faktor Kadaluwarsa dan All Unit Discount, Tesis tidak diterbitkan, Bandung: PPS UNPAR, 2012.

3. Limansyah, T. dan Lesmono, D., Model Persediaan Multi Item dengan Mempertimbangkan Faktor Kadaluarsa dan Faktor All Unit Discount, Jurnal Teknik Industri, 13(2), 2011, pp. 87-94.

4. Dye, C.Y., A Finite Horizon Deteriorating Inventory Model with Two-Phase Pricing and TimeVarying Demand and Cost under Trade Credit Financing using Particle Swarm Optimization, Swarm and Evolutionary Computation, 5, 2012, pp. 37-53.

5. Kumar, S., Kumar, P., and Saini, M., An Order Level Inventory Model for Deteriorating Items with Quadratic Demand Rate and Variable Holding Cost, International Journal of Scientific Research Engineering and Technology (IJSRET), I(5), 2012, pp. 253-263.

6. Mishra, V.K., Inventory Model for Time Dependent Holding Cost and Deterioration with Salvage Value and Shortages, Journal of Mathematics and Computer Science, IV(1), 2012, pp. 37-47.

7. Mishra, V.K., Singh, L.S., and Kumar, R., An Inventory Model for Deteriorating Items with Time-Dependent Demand and Time-Varying Holding Cost under Partial Backlogging, Journal of Industrial Engineering International, 9(4), 2013, doi:10.1186/2251-712X-9-4

8. Jaggi, C.K., and Khanna, A., An Integrated Production-Inventory-Marketing Model under Inflationary Conditions for Deteriorating Items, International Journal of Applied Decision Sciences, 1(4), 2009, pp. 435-454.

9. Dipak, K.J., Barun, D., and Tapan, K.R., A Partial Backlogging Inventory Model for Deteriorating Item under Fuzzy Inflation and 
Discounting over Random Planning Horizon: A Fuzzy Genetic Algorithm Approach. Advances in Operations Research, 2013, 2013, Article ID 973125. DOI:10.1155/2013/973125.

10. Muniappan, P., Uthayakumar, R., and Ganesh, S., An EOQ Model for Deteriorating Items with Inflation and Time Value of Money Considering Time-Dependent Deteriorating Rate and Delay Payments, Systems Science and Control Engineering, 3(1), 2015, pp. 427-434.

11. Nagare, M. and Dutta, P., Continuous Review Model for Perishable Products with Inventory Dependent Demand, Proceeding of the International Multi Conference of Engineers and Computer Scientist, Hong Kong, 2012.
12. Zhang, B. and Wang, X., Optimal Policy and Simple Algorithm for a Deteriorated Multi-Item EOQ Problem, American Journal of Operations Research, 1, 2011, 46-50

13. Nafisah, L., Sally, W., dan Puryani, Model Persediaan pada Produk yang Mendekati Masa Kadaluwarsa: Mempertimbangkan Diskon Penjualan dan Retur, Jurnal Teknik Industri, 18(1), 2016, pp. 63-72.

14. Levin, R.I., McLaughlin, C.P., Lamone, R.P., and Kottas, J.F., Productions/Operations Management: Contemporary Policy for Managing Operating Systems, McGraw-Hill, New York, 1972.

15. Silver, E.A. and Peterson, R., Decision Systems for Inventory Management and Production Planning, $2^{\text {nd }}$ ed. Wiley, New York, 1985. 